\title{
Overcoming the challenges to offer quality training in psychiatric nursing
}

\author{
Superando os desafios para oferecer formação de qualidade em enfermagem psiquiátrica \\ Superando los retos para ofrecer uma formación de calidad en enfermeira psiquiátrica
}

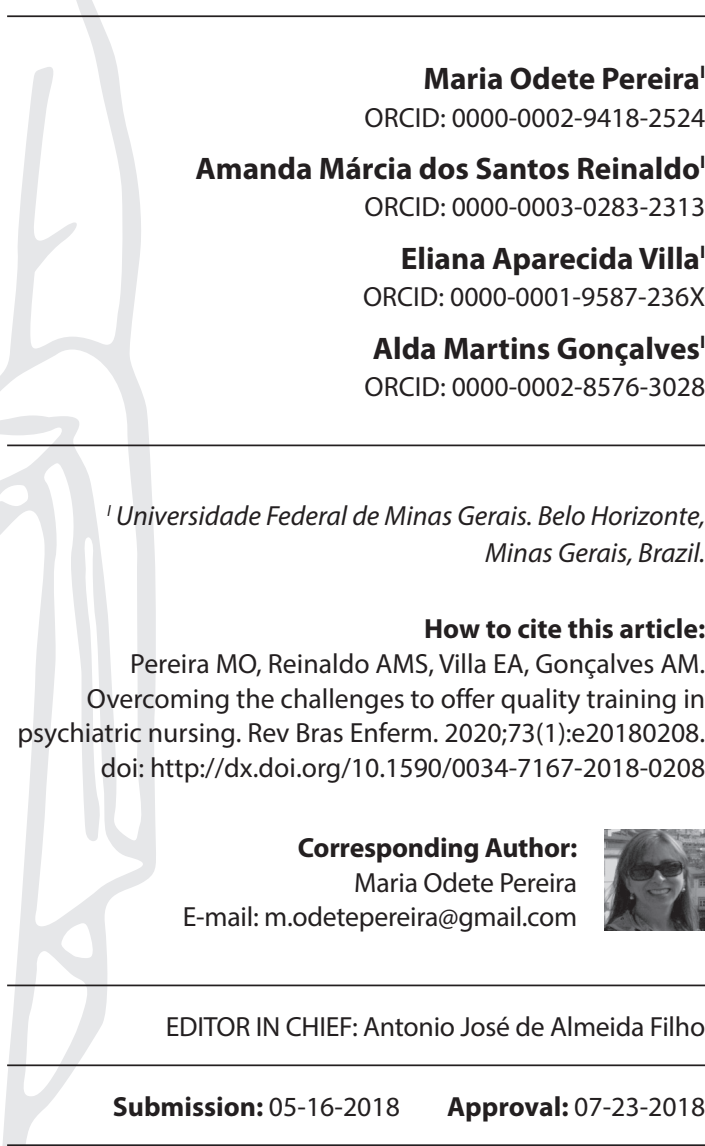

\begin{abstract}
Objective: to report the experience of the Psychiatric Nursing professors of the Nursing Undergraduate Course of the Nursing School, Universidade Federal de Minas Gerais (UFMG) and the challenges faced to offer quality training. Method: This is an experience report about the experience of Psychiatric Nursing professors of the Nursing Undergraduate Course of the Nursing School, UFMG. Results: After losing the workload of 120 hours in the Psychiatric Nursing Undergraduate Course, the area developed elective disciplines with a total of 330-hour load, in addition to extension and research projects. Final considerations: the precariousness of the area of Nursing training after curricular restructuring in a higher education institution, whether in relation to hour load or in the allocation of teaching vacancies, is in line with advances of the Brazilian Psychiatric Reform and epidemiological data of psychic illness and drug use.

Descriptors: Psychiatric Nursing; Mental Health; Holistic Nursing; Education, Nursing; Mental
\end{abstract} Disorders.

\section{RESUMO}

Objetivo: Relatar a experiência das docentes da área de Enfermagem Psiquiátrica do Curso de Graduação em Enfermagem da Escola de Enfermagem da Universidade Federal de Minas Gerais e os desafios enfrentados para ofertar um ensino de qualidade. Método: Tratase de um relato de experiência acerca da vivência das docentes da área de Enfermagem Psiquiátrica da Graduação de Enfermagem da Escola de Enfermagem da UFMG. Resultados: Com a perda de 120 horas para o ensino de Enfermagem Psiquiátrica na graduação, a área lançou mão das disciplinas optativas, que totalizam 330 horas, além de projetos de extensão e pesquisa. Considerações finais: a precarização de uma área de formação do enfermeiro após reestruturações curriculares em uma instituição de ensino superior, quer seja em relação às cargas horárias ou na alocação de vagas docentes, vai de encontro aos avanços da Reforma Psiquiátrica brasileira e aos dados epidemiológicos de adoecimento psíquico e uso de drogas.

Descritores: Enfermagem Psiquiátrica; Saúde Mental; Enfermagem Holística; Educação em Enfermagem; Transtornos Mentais.

\section{RESUMEN}

Objetivo: informar sobre la experiencia de los profesores de Enfermería Psiquiátrica de la Graduación de Enfermería de la Escuela de Enfermería de la Universidade Federal de Minas Gerais (UFMG) y los desafíos enfrentados para ofrecer una enseñanza de calidad. Método: Este es un informe de experimento sobre la experiencia de los maestros del área de Enfermería Psiquiátrica de la Graduación de Enfermería de la Escuela de Enfermería de la UFMG. Resultados: Con la pérdida de 120 horas en la enseñanza de Enfermería Psiquiátrica a nivel de graduación, el área desarrolló las asignaturas optativas, que totalizan 330 horas, además de proyectos de extensión e investigación. Consideraciones finales: la precariedad de un área de capacitación de enfermeras después de la reestructuración curricular en una institución de educación superior en relación con las cargas horarias o en la asignación de vacantes de enseñanza, está en línea con los avances de la Reforma Psiquiátrica Brasileña y los datos epidemiológicos de enfermedad psíquica y uso de drogas. Descriptores: Enfermería Psiquiátrica; Salud Mental; Enfermería Holística; Educación en Enfermería; Trastornos Mentales. 


\section{INTRODUCTION}

The history of classical psychiatry reminds us of the dominant biologicist logic in society and among health professionals, where psychic disorders were reduced to the physical and biological model. The understanding of people in psychic suffering was restricted and relegated to lack of care without any kind of approach that was actually therapeutic and centered on human needs ${ }^{(1)}$.

Any reference to subjective issues of human suffering was disregarded. Prevailed the denial of existence of a subject marginalized by society and called "crazy", who succumbed to medical knowledge and power relations ${ }^{(1-2)}$.

In this sense, asylum psychiatric interventions were ineffective, as confirmed by the high rates of hospitalizations, readmissions and social incapacitation ${ }^{(1)}$. However, the confinement of subjects in psychiatric hospitals resulted in the mobilization of workers, family members and patients, who organized themselves in social movements that contested the hegemonic knowledge and, consequently, focused on the redirection of knowledge and practice in the area ${ }^{(1)}$.

The look at the mentally insane subject, separated from the social space and without the right to full exercise of citizenship was reproduced in academic spaces, where discourses of humanization and holistic care, integrality and interdisciplinarity did not contemplate subjects related to psychic illness and problematic use of psychoactive substances. Thus, the clashes between disciplines of curricular structures placed Psychiatric Nursing in the "cursed corner"(3) of invisibility ${ }^{(4)}$.

Historically, in nursing curricula, some disciplines have privileged hours, although the training of nurses must prioritize individual and collective multidimensional care throughout the life cycle.

As the history of Nursing is written and inscribed in the historicity of the health area with the aim to establish itself as knowledge and practice and seeks answers for its concerns, this movement is done in many ways, many of which are mistaken in curricula adopted in undergraduate courses ${ }^{(4)}$.

The relevance of the present article is the problematization of the issue, because although other studies on Psychiatric Nursing training were developed ${ }^{(5-10)}$, in none of them was questioned the loss of workload of this area in Nursing curricula.

The authors propose a reflection on training in Psychiatric Nursing and Mental Health (Portuguese acronym: EPSM), because they believe a consistent and reflexive training will allow general nurses to be resolute in mental health care since in some cases, nurses'role in the Psychosocial Care Network (Portuguese acronym: RAPS) has weaknesses and difficulties with management of cases in the units ${ }^{(11-12)}$

\section{OBJECTIVE}

To report the experience of professors of the Psychiatric Nursing and Mental Health department of the Undergraduate Nursing Course of the Nursing School, Universidade Federal de Minas Gerais, the challenges faced, and the strategies used to offer quality training.

\section{METHOD}

This is an experience report of Psychiatric Nursing and Mental Health professors of the Nursing School, Universidade Federal de
Minas Gerais (Portuguese acronym: EEUFMG). This text addresses the losses of professors and hour load in the department throughout the two last decades, as opposed to the compensatory strategies adopted for the consistent training of prospective nurses.

The experience report is a descriptive research tool based on reflection of an action or set of actions that addresses a situation experienced in the professional scope of interest of the scientific community ${ }^{(13)}$. This is an effective methodology for the authors' report and discussion on the teaching experience in Psychiatric Nursing and Mental Health in the Undergraduate Nursing Course of the Universidade Federal de Minas Gerais between 1996 and 2018.

The analysis of the authors' teaching experience is from the perspective of the critical theory to colonialism of Boaventura de Sousa Santos. According to the sociologist, we were all socialized on the idea that anticolonial liberation struggles of the twentieth century put an end to colonialism, but this is not true, since it only changed form or appearance, and this makes it difficult to properly name it ${ }^{(14)}$. However, it does not conceal nor diminish the suffering of its victims in everyday life. For Santos (2018), insidious colonialism is gaseous and evanescent, invasive and evasive, at last, cunning. This colonialism occurs in the streets, homes, prisons and universities, in all social spaces ${ }^{(14)}$.

\section{RESULTS}

Teachers chose to contextualize the training in Psychiatric Nursing and Mental Health in the EEUFMG from the 1990s, a historical moment in which the Brazilian Psychiatric Reform redirected the mental health care model with the implementation of community care services for people in psychic distress ${ }^{(15)}$.

\section{The challenges faced by the area of Psychiatric Nursing}

In March 2018, the Nursing School of the Universidade Federal de Minas Gerais - EEUFMG formed the $124^{\text {th }}$ class of Nurses, a trajectory that started in 1933. At that time, it was a public school and formed mid-level professionals, as used to be the practice. In 1950, it was annexed to the Faculty of Medicine of UFMG and functioned as its department until 1968, when, after the university reform, it became an autonomous unit and began training higher level professionals.

Throughout these years, the EEUFMG underwent curricular reforms, significantly expanded its teaching, research, extension and administration activities. The number of vacancies for incoming students increased, as well as the number of teachers and administrative technicians, departments, disciplines, postgraduate courses and other undergraduate courses (Nutrition in 2004 and Health Services Management in 2009).

The growth of the institution impacted on the teaching and recognition of new health needs of the population pointed especially by the Sanitary and Psychiatric Reforms that motivated the creation of other teaching, research and extension activities with consequent expansion of teaching-learning scenarios.

In the period of continuous implementation of the set of changes in the 1990s, the Psychiatric Nursing and Mental Health department had seven teachers, who offered a discipline $(180 \mathrm{~h}$ 
workload) in the undergraduate course and a specialization course also called Psychiatric Nursing (PN) that was considered reference in the state of Minas Gerais.

From 1993 to 1996, there was an intense movement in the mental health policy of Belo Horizonte with participation of several sectors and health workers, instigated by the movement of workers, users and their families ${ }^{(15)}$.

In order to offer an innovative teaching in opposition to the hospital-centered logic and to strengthen the anti-asylum fight, the Psychiatric Nursing and Mental Health department of the EEUFMG began activities of clinical teaching in a community service of mental health care denominated Center of Reference in Mental Health (Portuguese acronym: CERSAM) ${ }^{(15)}$. Thus, the EEUFMG pioneered the teaching of psychiatric nursing beyond the walls of the psychiatric hospital.

In 1996, the School of Nursing underwent a process of curricular change and, contrary to the historical and political health movement that discussed the expansion of mental health care in the Primary Care Network, the hour load of the department was reduced. The Psychiatric Nursing discipline of $180 \mathrm{~h}$ load (45h theoretical and $135 \mathrm{~h}$ practice) began to have a total load of $60 \mathrm{~h}$ (30h theoretical and $30 \mathrm{~h}$ practice), a reduction of 120 hours (2/3 of its workload). Such a change disrupted the proposals under construction in the department, and teachers of the EPSM were mandatorily relocated to other departments ${ }^{(15)}$, such as Administration, Pedagogy (Undergraduate Nursing course focused on teaching) and Scientific Methodology ${ }^{1}$. Only five teachers remained in the department.

In 2001, with publication of curricular guidelines for the Undergraduate Nursing training, in the EEUFMG, was proposed the integration of PN contents with other areas of knowledge, such as: women's health; child and adolescent health; collective health; semiology and curricular internship in primary and secondary care. The justification for integration was based on the interface of mental health with the mentioned specialties. The strategy resulted in some specific classes in those disciplines, but little by little, the contents disappeared.

Since the beginning of the 2000s, the National Mental Health Policy and the epidemiological studies have shown an increase in psychic illness and problems caused by the abusive use of psychoactive substances in the worldwide and Brazilian population. In 2005, the EEUFMG underwent a new curricular restructuring that came into effect in 2009. In this change, the department of Psychiatric Nursing and Mental Health was assigned with the total of $120 \mathrm{~h}$ load divided into two compulsory subjects: Mental health with 45h load (in the third term); and Psychiatric Nursing with $30 \mathrm{~h}$ load of theoretical content and $45 \mathrm{~h}$ load of clinical teaching (in the eighth term).

In 2006, two teachers retired and two years later, a vacancy was assigned to the department. In 2014, one more vacancy was filled. Thus, in 2015, the department had five teachers developing teaching, extension, research and administrative activities.

1 Part of the text used for the development of this article was extracted from the letter prepared to the Permanent Teaching Commission of UFMG in May 2017 as justification for the request of two vacancies for a permanent professor, as a result of two retirements in that year.
In the second semester of 2017, after the retirement of two faculty members, two vacancies for substitute professors were transferred to the EPSM department. After the selection process, the academic semester in 2018 began with two substitute professors. However, one of them had only three credits in the discipline of $\mathrm{PN}$, and the remaining workload (nine credits) was allocated to the Administration department without the consent of Psychiatric Nursing and Mental Health. In June 2018, the EPSM department held a public concourse for assistant professor, and the two vacancies created with the latest retirements of professors were filled.

In this brief history, was problematized how the losses suffered after the last two curricular restructuring processes in the EPSM department affected the work process of professors, since teaching, extension and research are the pillars for a good formation. The reduced faculty of the department assumed all activities inherent to the undergraduate course, object of work and support of the University, by developing teaching, extension and research projects in the course.

Professors in the department develop research and extension projects, are involved in internal and external administrative representations with a social role in mental health and human rights, in the Brazilian Nursing Association, and in the intersectoral mental health network of the municipality. Two professors are also involved in Postgraduate Nursing Programs, and in Health Services Management of the School of Nursing and the Faculty of Medicine of the UFMG.

\section{The offer of elective disciplines as a complementary strat- egy in Psychiatric Nursing and Mental Health training}

Initially, the elective courses were offered in the disciplines of Mental Health and Society; Chemical Dependence in Adolescence; and Care, Clinic and Subjectivity. Subsequently, after hiring the last two faculty members, the number was expanded and the knowledge and practices of the area, which are fundamental in the care of people, families and communities, were offered to undergraduate students.

However, one questions to what extent this strategy replaces the knowledge needed to train nurses for mental health care. As these are not mandatory contents and practices of the syllabus, not all students attend elective courses ${ }^{(16)}$.

In the curricular structure of 2018, the EPSM department offers undergraduate students two compulsory subjects and nine elective disciplines in a total of 330 hours and each class lasts 60 minutes. The disciplines offered are shown in Table 1.

Three disciplines address issues related to mental health, and the others deal with issues of mental health, alcohol, and other drugs (psychoactive substances - PSs).

The contents relate to the problematic use of psychoactive substances as a public health problem; good practices in the treatment and psychosocial approaches to abusive use of PSs; study of chemical dependencies in their general aspects, specific prevention and treatment in adolescence; strategic actions to prevent the use of PSs; implementation and maintenance of public policies at the local level with emphasis on children and adolescence; historical, political and social contextualization of mental disorders in Brazil; psychiatric reform; public policies on mental health and PSs. 
Table 1 - Elective disciplines of the Psychiatric Nursing and Mental Health department, School of Nursing, Universidade Federal de Minas Gerais, according to title and hour load, Belo Horizonte, Minas Gerais, Brazil, 2018

\begin{tabular}{lc}
\hline \multicolumn{1}{c}{ Discipline } & Hour load \\
\hline Good practices in the treatment of chemical dependence & 30 hours \\
Chemical dependence in adolescence & 30 hours \\
Populational aging and elderly health care & 30 hours \\
Prevention of drug use & 30 hours \\
Mental health at the General Hospital & Theory: 30 hours - Practice: 15 hours \\
& Total = 45 hours \\
Mental health and Society & 30 hours \\
Topic on mental health: care, clinic and subjectivity & 30 hours \\
Topic on mental health: public policies on mental health, alcohol and other drugs & 45 hours \\
Topics in Nursing: technologies for intervention in mental health and with psychoactive substance users & 45 hours \\
\hline
\end{tabular}

Source: Table developed with information available on the website of the UFMG School of Nursing.

Common issues to mental health and care to users in problematic use of PSs are addressed, such as: psychosocial care network; intersectoriality; mental health in its care dimensions to people in psychological distress after suffering and treating clinical and surgical diseases in the hospital environment; the role of nurses in mental health care in the general hospital; interpersonal relationship; therapeutic communication; listening and therapeutic relationship as instruments for mental health care in the general hospital; teamwork; interdisciplinarity and inclusion of the family as a necessary condition for health care; practical activities of mental health care in the hospital environment.

Theoretical and methodological approaches are also addressed, such as: Nursing care in its clinical perspective based on Lacanian psychoanalytic theory; communication and therapeutic relationship; tracing of abusive use of PSs; and brief interventions as care technologies for people in mental distress and/or problematic use of PSs, among others.

The main pedagogical strategies used in the disciplines are: conversation wheels; discussion groups; reading and discussion of articles; book reading; lectures and dialogic classes; movies and documentaries. Three elective courses are offered in a virtual learning environment (VLE) through the Moodle platform, according to the recommendation by the Ministry of Education that 20\% of the undergraduate course workload must be offered via VLE.

\section{DISCUSSION}

By considering the national and global context of psychiatric illness and abusive use of psychoactive substances, the authors concluded that the curricular restructuring, and consequently, the construction of the Political and Pedagogical Project of the Nursing undergraduate course of the EEUFMG were not widely discussed. This was also observed in a study in which the objective was to analyze how the Psychiatric Nursing and Mental Health teaching occurs in public nursing courses in the state of São Paulo, and to investigate and analyze the pedagogical practice of professors responsible for disciplines in the area ${ }^{(5)}$.

The author ${ }^{(5)}$ has found among participants of her study that the contents prioritized the study of psychopathologies and signs and symptoms of diseases with less focus on attitudinal and procedural contents. However, in our reality, we have discussed these topics in discussion groups where students construct conceptual maps for an easier understanding of contents. The disciplines of the EPSM area in our context address issues related to public policies from the perspective of psychiatric reform and psychosocial rehabilitation.

There is a departmental culture, particularly among teachers from other areas, that Psychiatric Nursing and Mental Health does not have expressive production of scientific researches hence, there is no need for new professors' vacancies. Regardless of concourses for hiring professors at the UFMG for performing activities based on the pillars that guarantee the excellence in undergraduate courses, such as teaching, extension and research, in public universities, teaching and research activities are more appreciated in postgraduate studies than in undergraduate studies.

Professors who reported their experience here perceive the colonialist logic in Brazil present in the speeches of colleagues from other areas of the course, especially in the west and north of the country, where the struggle for land ownership goes beyond ethical, citizenship and human rights issues ${ }^{(17)}$. This logic descends from Portuguese colonialism.

In Brazil, Portuguese colonialism promoted a sociopoliticalcultural de-characterization of native people. Their lifestyle disappeared, and the mechanisms of reproduction of the colonial model and other European models remained ${ }^{(18)}$.

The authors agree with Santos in the affirmation that "colonialism consists in the ignorance of reciprocity and inability to conceive the other in a way that is not as an object. The aim of colonialism is the order, regulation"(19), in short, control.

Although public universities use post-colonialist strategies for hiring teachers, in institutional units there are still some colonialist practices in dominant discourses for manipulating collegiate bodies that in turn lose their legitimacy.

In addition, even though concourses for higher education professors are intended for hiring the teaching staff for undergraduate education, the number of scientific publications is often prioritized to the detriment of the potential contribution of the candidate for the training of future nurses. Less value is given to professors' pedagogical training and their experience in service ${ }^{(5)}$. Unfortunately, this logic is stimulated and sustained by Research Development Institutions in Brazil.

Currently, when discussing new national guidelines for nursing training in Brazil, it is necessary to invest in nurses' training and assign a higher curricular workload for Psychiatric Nursing and Mental Health with the objective of the quality of training of 
future nurses. Everyone should have access to the same content and develop skills and abilities that allow a differentiated attitude towards the person in psychological distress and/or problematic use of PSs ${ }^{(5)}$.

Note that in the psychosocial field, Nursing works in a multidisciplinary team in the perspective of interdisciplinary work and should play a more comprehensive role with active participation in the treatment and autonomous exercise of the profession ${ }^{(6)}$.

Nurses are expected to have scientific technical conditions to propose actions aimed at relational therapeutic proposals in which power relations between the professional and the person seeking care are transformed. Professionals must develop skills and abilities for an assertive approach and relationship.

\section{Limitations of the Study}

The limitation of the study is associated with its restriction to the reality of an academic unit of a federal educational institution and the low scientific production reporting similar cases elsewhere for comparisons and propositional discussions.

\section{Contributions to the Area of Nursing, Health or Public Policy}

The study contributes to the discussion of teaching of Psychiatric Nursing and Mental Health in undergraduate studies as a field of specific knowledge with interface in different areas of knowledge in Nursing. The nature of mental health care and the psychiatric reform were considered, as these put the person in mental distress on the scene through components of the psychosocial care network within the Unified Health System (Brazilian SUS).

At a time when the national curricular guidelines of the Nursing undergraduate course are being reviewed, this study contributes to the problematization of training in the department of EPSM so that it does not occur in the perspective of transversality along the training course, and includes theoretical-practical disciplines in curricular structures with hour loads that enable the development of skills, competencies and attitudes for nurses' resolutive action in the different care points of the psychosocial care network.

New studies that record a picture of the EPSM in public and private institutions of Nursing undergraduate education are needed by considering the potential of nurses in this area. A good undergraduate education is imperative to this end.

\section{FINAL CONSIDERATIONS}

In the last decades, the hour load of courses in the Psychiatric Nursing department of the EEUFMG has been reduced. In response and committed to the training of nurses, their professors implemented seven elective disciplines offered in the two semesters as a strategy to train competent nurses for the comprehensive care of users in all services of the Unified Health System.

The present experience report discussed the precariousness of an area of training and practice of nurses within a higher education institution in a timeline that shows the damages to the department in relation to the hour load assigned to after successive curricular reforms, and in the allocation of teaching vacancies. Such practices go against mental health advances as public policy in the country until the year 2016 and the projections for mental illness of the world population in the next 20 years.

In the country, the current scenario of mental health as a public policy is fragile and undergoes changes that disregard the desire of users and workers. Nursing is a profession that stands ahead of these discussions in the sense of proposing actions that preserve the rights conquered by citizens, such as a dignified and quality care in health and mental health. To this end, nurses' training is part of the strengthening of this area in undergraduate courses.

\section{FUNDING}

To the research Dean of the Universidade Federal De Minas Gerais (Edital 02/2019) for the financial support for payment of the publication fee.

\section{REFERENCES}

1. Barbosa VFB, Martinhago F, Hoepfner MAS, Daré PK, Caponi SNC. O cuidado em saúde mental no Brasil: uma leitura a partir dos dispositivos de biopoder e biopolítica. Saúde Debate. 2016;40(108):178-89. doi: 10.1590/0103-1104-20161080015

2. Foucault M. História da loucura na idade clássica. $6^{\mathrm{a}}$ ed. São Paulo: Perspectiva; 2008.

3. Bueno AC. Canto dos malditos. São Paulo: Rocco; 2004.

4. Maftum MA, Alencastre MB. A prática e o ensino de Enfermagem em saúde mental e psiquiátrica no Brasil: questões para reflexões. Cogitare Enferm. 2002;7(1)61-7. doi: 10.5380/ce.v7i1.32558

5. Maftum MA, Pagliace AGS, Borba LO, Brusamarello T, Czarnobay J. Changes in professional practice in the mental health area against brazilian psychiatric reform in the vision of the nursing team. J Res Fundam Care Online. 2017;9(2):309-14. doi: 10.9789/2175-5361.2017. v9i2.309-314

6. Magnago C, Tavares CMM. O ensino de Enfermagem psiquiátrica nas Universidades Públicas do Estado do Rio de Janeiro. Rev Eletr Enf. 2012;14(1):50-8. doi: 10.5216/ree.v14i1.10626

7. Esperidião E, Silva NS, I, Caixeta CC, Rodrigues J. A Enfermagem Psiquiátrica, a ABEn e o Departamento Científico de Enfermagem Psiquiátrica e Saúde Mental: avanços e desafios. Rev Bras Enferm. 2013;66(esp):171-6. doi: 10.1590/S0034-71672013000700022

8. Fernandes JD, Sadigursky D, Silva RMO, Amorim AB, Teixeira GAS, Araújo MCF. Teaching psychiatric nursing/mental health: its interface with the Brazilian Psychiatric Reform and national curriculum guidelines. Rev Esc Enferm USP. 2009;43(4):955-60. doi: 10.1590/ S0080-62342009000400031 
9. MCBM. The Psychiatric Nursing/Mental Health Education: advances, limitations and challenges. SMAD, Rev Eletrônica Saúde Mental Álcool Drog. 2016;12(3):139-46. doi: 10.11606/issn.1806-6976.v12i3p139-146

10. Contieri MP. O ensino da Enfermagem psiquiátrica na graduação em escolas brasileiras: uma revisão bibliográfica [monografia] [Internet]. Marília: Faculdade de Medicina de Marília; 2014 [cited 2018 Jun 30]. Available from: http://ses.sp.bvs.br/lildbi/docsonline/get.php?id=4444

11. Oliveira EC, Medeiros AT, Trajano FMP, Chaves Neto G, Almeida SA, Almeida LR, et al. O cuidado em saúde mental no território: concepções de profissionais da atenção básica. Esc Anna Nery. 2017;21(3):e20160040. doi: 10.1590/2177-9465-ean-2017-0040

12. Sobral FR, Campos CJG. Nurses and mental health education in primary care: an integrative review. SMAD, Rev Eletrônica Saúde Mental Álcool Drog [Internet]. 2012 [cited 2018 Jun 30];8(2):100-7. Available from: http://pepsic.bvsalud.org/scielo.php?script=sci_arttext\&pid $=$ S1806-69762012000200008

13. Marini ZM, Arrieira I, Jacotec C. Relato de experiência da equipe odontológica em atenção domiciliar em um hospital-escola na cidade de Pelotas, RS, Brasil. RFO UPF. 2017;22(2):158-61. doi: 10.5335/rfo.v22i2.6747

14. Santos BS. El colonialismo insidioso. El Correo [Internet]. 2018 [cited 2018 Jun 30]; Available from: http://www.elcorreo.eu.org/IMG/article_ PDF/El-colonialismo-insidiosoBoaventura-de-Sousa-Santos_a27059.pdf

15. Villa EA, Cadete MMM. Portas abertas: novas possibilidades no ensino da enfermagem psiquiátrica. Rev Latino-Am Enfermagem. 2000;8(6):13-9. doi: 10.1590/S0104-11692000000600003

16. Universidade Federal de Minas Gerais (UFMG). Escola de Enfermagem. Disciplinas optativas [Internet]. Belo Horizonte: UFMG; 2018 [cited 2018 Jun 30]. Available from: http://www.enf.ufmg.br/index.php/disciplinasoptativas

17. Pereira MO, Barros $\mathrm{S}$, Oliveira MAF. Reflexão acerca das políticas públicas brasileiras na óptica do póscolonialismo. Rev Enferm UFPE On Line. 2010;4(2):730-8. doi: 10.5205/1981-8963-v4i2a6210p730-738-2010

18. Silva SD, Moura TTRL, Campos FI. A terra dos coronéis no Oeste do Brasil: A cattle frontier, violência e dominação fundiária no Cerrado goiano. Topoi (Rio J.). 2015;16(30):234-59. doi: 10.1590/2237-101X016030009

19. Santos BS. Para além do pensamento abissal: das linhas globais a uma ecologia de saberes. 2007;79:71-94. doi: 10.1590/ S0101-33002007000300004 